\title{
Attendance System of Computer Laboratory Assistant in PT.XYZ Using Wireless Fidelity
}

\author{
Rahmat Sulaiman $^{* 1}$, Agustina Mardeka Raya ${ }^{2}$, Tri Sugihartono ${ }^{3}$, Fransiskus Panca \\ Juniawan $^{4}$, Ayu Ratna Juwita \\ ${ }^{1,3,4}$ Informatic Engineering, Faculty Of Information Technology, ISB Atma Luhur \\ ${ }^{2}$ Information System, Faculty Of Information Technology, ISB Atma Luhur \\ ${ }^{5}$ Informatic Engineering, Faculty Of Information Technology, Buana Perjuangan University \\ E-mail: "11 rahmatsulaiman@ atmaluhur.ac.id, ${ }^{2}$ agustinamardekaraya@atmaluhur.ac.id, \\ 3trisugihartono@atmaluhur.ac.id, ${ }^{4}$ fransiskus.pj@ atmaluhur.ac.id, ${ }^{5}$ ayurj@ubpkarawang.ac.id
}

\begin{abstract}
The use of Android smartphones is becoming increasingly widespread in all walks of life in people's daily lives. Supported by the development of mobile applications that are so innovative and varied, is one of the reasons. Mobile application development aims to support almost all human activities, especially in the world of work, therefore the programmer creates a presence system using Android-based wireless fidelity (WIFI) at laboratory of PT.XYZ. At the laboratory of PT.XYZ, they still use manual attendance system for presence of computer laboratory assistant, so there are several problem like productivity decreases due to fraud in attendance, namely the help of friends to be absent without having to be present, to data errors. Through wireless fidelity programmers solve problems with prototype research models and Object Oriented Programming (OOP) methods. The software development tool is the Unified Modeling Language (UML). The Applications has made using hash function of encryption on admin passwords and the user passwords. Both of the encryptions work on private passwords, even the admin and programmers don't know the contents of the user's password. The main result of this research is we can provide that there's many way to make presence system one of them uses WIFI.
\end{abstract}

Keywords - Attendance System, Wifi Attendance System, Wireless Fidelity Presence System, Presence System.

\section{INTRODUCTION}

Lately the use of Android smartphones is becoming increasingly widespread in all over the world. Supported by the development of mobile applications that are so innovative and varied, is one of the reasons. Mobile application development aims to support almost all human activities, such as games, calculators, social media, and also specifically supports teaching and learning activities. PT.XYZ is one of the universities in Bangka Belitung that has a study in the field of informatics engineering. As one of the universities that has the study of informatics engineering, it must have a computer laboratory (labkom) with national standards, therefore to improve laboratory performance, it must have a good presence for laboratory assistant, especially laboratory assistants (Aslab).

Manual attendance may seem more cost-effective because there is no need to use special technology to record employee attendance. However, indirectly, relying on human 
resources to manage attendance will add to its own costs for the company. However, using manual system for attendance. Because it relies on a manual system, of course it will be very susceptible to errors or data manipulation due to manual systems. Not to mention there are employees who are sick or are not allowed to enter. There is no one in charge of entering the data so it is difficult to recap. Manual system has another several problems for the Performance of PT. XYZ Laboratory, Like productivity decreases due to fraud in attendance, namely the help of friends to be absent without having to be present, to data errors. The presence process is a process that supports the performance of PT.XYZ laboratory assistant. Through technological developments, the researchers makes an application for a laboratory assistant attendance system at PT.XYZ using Android-based wireless fidelity (wifi) so that the campus can process the attendance system better. Through several references and existing research, the researchers get a lot of android attendance application development using Near Field Communication (NFC) and Radio Frequency Identification (RFID) technology. In this application the system will run when connected to wifi which has been systemized in the application program, so automatically employees or employees will be absent. The way the application works is by reading the MAC address that has been input into the database. In this case the application designer uses the MAC address because the MAC address is permanent, not like the IP address which can change when connected to another wifi

\section{RESEARCH METHOD}

The system development model used is a prototype model. This model was chosen because it pays more attention to the needs of the user's system, overall this model prioritized of user satisfaction. The stages of the prototype model are as follows:

1. System Requirements

The head of PT.XYZ computer laboratory assistant and the researchers are gather and meet to discuss and define the format of the entire software, identify all requirements, and outline of the system. For an example, the requirements to be able to identify the MAC address of a computer laboratory assistant and store attendance data and etc.

2. Prototype

Build a prototype by making a temporary design that focuses on laboratory assistants for attendance system application, the users using wifi as an example of making an interface design for presence system.

3. Prototype Evaluation

The evaluation is carried out by laboratory assistants who use the presence system using wifi, whether the prototype that has been built is in accordance with their wishes or not. If it is appropriate, then the next step will be taken. But if not, the prototype is revised by repeating the previous steps. This step will continue to be repeated until The head of PT.XYZ computer laboratory assistant and PT.XYZ computer laboratory assistant states that the prototype is as needed.

4. Coding system In this stage the agreed prototype is translated into a programming language suitable for image processing, namely Android Studio.

5. Test the system After the system is ready to use software. Testing must be carried out first before conjoined in use. The test in question uses the Black Box. 
6. System evaluation The tool evaluates whether the finished software is as expected. If it is appropriate, the process will proceed to the next stage. However, if the finished software is not as expected, then the previous stage will be repeated

7. Using the system Tested and customer-accepted software ready to use.

\section{System Development Method}

Object Oriented Programming (OOP) is an approach to software development. The structure in the software is based on the interaction of objects in the completion of a process or task. The interaction takes the form of messages and sends them back between the objects. The object will respond to the message into an action or method. Object Oriented Programming (OOP) is an object-oriented programming method for the purpose of OOP created to facilitate program development by following models that already exist in everyday life. So, every part of a problem is an object, the object itself is a combination of several smaller objects. The concept of OOP is more than just a programming concept.

\section{System Development Tools}

The system development tool used is UML (unified modeling language). UML is a visual language for modeling and communicating a system using diagrams of supporting texts, namely:

1. Activity Diagrams

Activity diagram describe a system activity or process that is currently running to make it easier to understand. There are two Activity diagrams in this study : Activity diagrams Registration and Activity diagrams the main menu.

2. Use Case Diagrams

Use Case Diagram describes the system modeling that will be proposed. Use Case Diagrams make it easier to map the functional requirements obtained from the analysis phase. There are 4 use case diagrams in this study, namely use case diagrams for attendance management, use case diagrams for ASLAB verification, use case diagrams for registration, and use case diagrams for ASLAB attendance diagrams.

3. Class Diagrams

Class diagrams describe the structure of the system from defining classes to building the system.

4. Sequence Diagrams

Sequence Diagram describes the interaction between functions in a class or with functions in different classes. Sequence diagrams make it easier to know the functions in one class.

5. Package Diagrams

Package Diagrams provide a way to assemble interrelated elements in UML diagrams.

\section{RESEARCH RESULTS AND DISCUSSION}

The prototype method is a software development method that allows interaction between system developers and system users, so as to overcome incompatibility between developers and users. The prototype development model is depicted in Figure 1. 


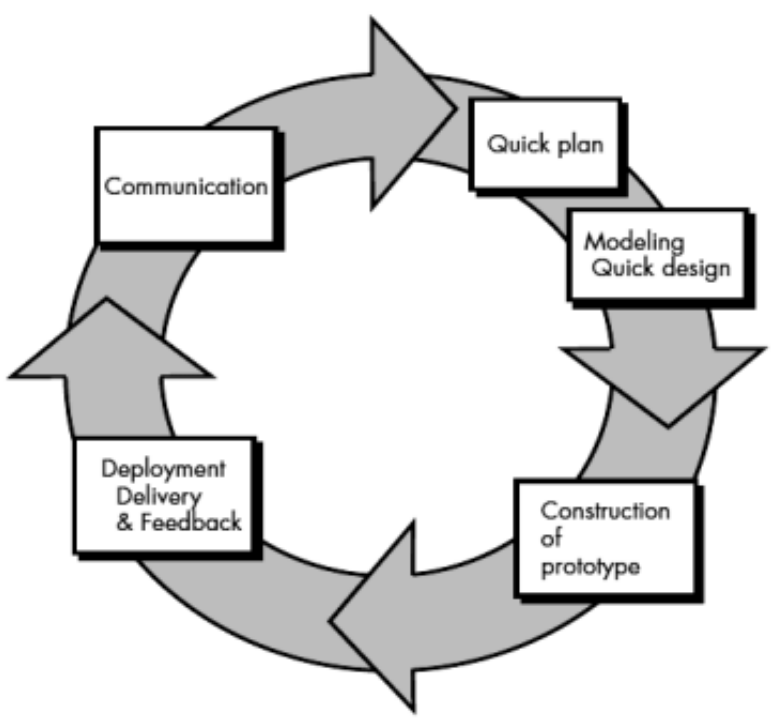

Figure 1. Prototype Model

The following stages of the system development method used in this research:

1) Communication.

The initial stages of the prototype model are to identify existing problems, as well as other information needed to build the system.

2) Planning.

This stage is carried out by determining the resources, specifications for development based on system requirements, and objectives based on the results of communication carried out so that development can be as expected.

3) Modeling

Modeling The next stage is to represent or describe the system model to be developed such as a process designed using the Unified Modeling Language (UML). In this stage, the prototype built with a temporary design system is then evaluated against the customer whether it is in accordance with what is desired or not still need to be re-evaluated. After the system is considered in accordance with what the customer expects, the next step is to create an application (coding) from the system design that is made translated into the Codeigniter Framework programming language which is integrated with MySQL database users.

4) Construction.

This stage is used to build a prototype and test the system built. The installation process and the provision of user support are also carried out so that the system can run properly

5) Finishing.

This stage is needed to get feedback from users, as a result of the evaluation of the previous stages and the implementation of the developed system

\section{Analysis Requirements}

in this stage, an analysis of the needs of the application to be developed is carried out, this needs analysis is divided into functional requirements and non-functional requirements. 


\subsection{Functional Requirements}

This analysis is carried out to identify what facilities and activities are carried out by the system. The functional requirements in the development of this application are as follows:

a. Administrators can open the main menu to use applications made on the web admin and android. Admin can enter laboratory assistant data through data input on the web admin which consists of ID, Nim, and Name. In addition, the admin must process laboratory assistant data as a report.

b. Users (laboratory assistants) can register on android and assistant data can be stored in the database. Users can login to android as a sign that the user has made attendance. But before that, the user must be connected to a WIFI network that is available through the user's smartphone.

\subsection{Use Case Diagram}

The admin and user use case diagrams are used to find out what functions are in the system and who has the right access to use these functions. The admin use case diagram is shown in Figure 2, and the Aslab use case diagram is shown in Figure 3.

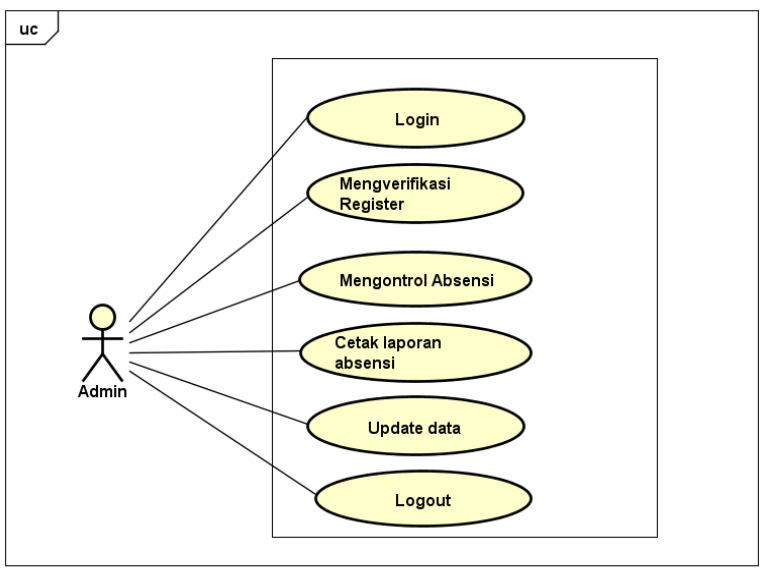

Figure 2

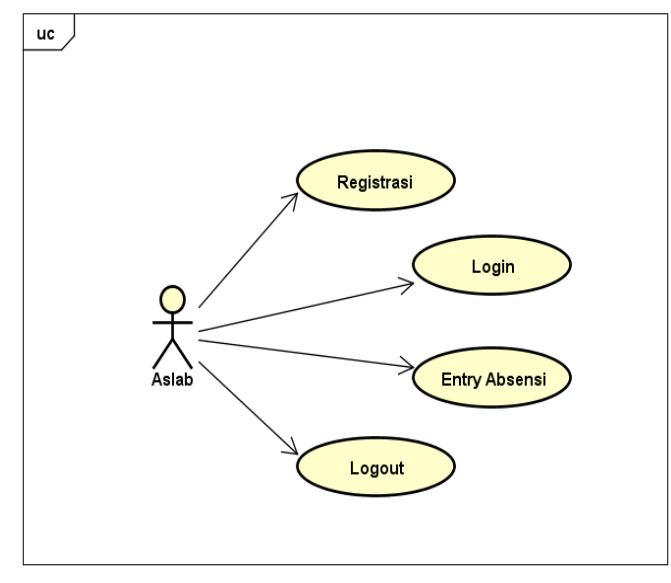

Figure 3

\subsection{System Design}

In this system design, it will explain activity diagrams, sequence diagrams and class diagrams of the proposed system.

a. System Analysis

Based on the description of the problem analysis on the system running above, the analysis of the solution results that can be given is to use an android-based presence system through a wireless fidelity network in the computer laboratory at PT.XYZ 
b. Activity Diagram

Figure 4 ASLAB opens the android application and logs into the application. Login fails if aslab is not registered in the database. Login is successful and the system is automatically present on the admin dashboard and logout aslab indicates that the work schedule has been completed.

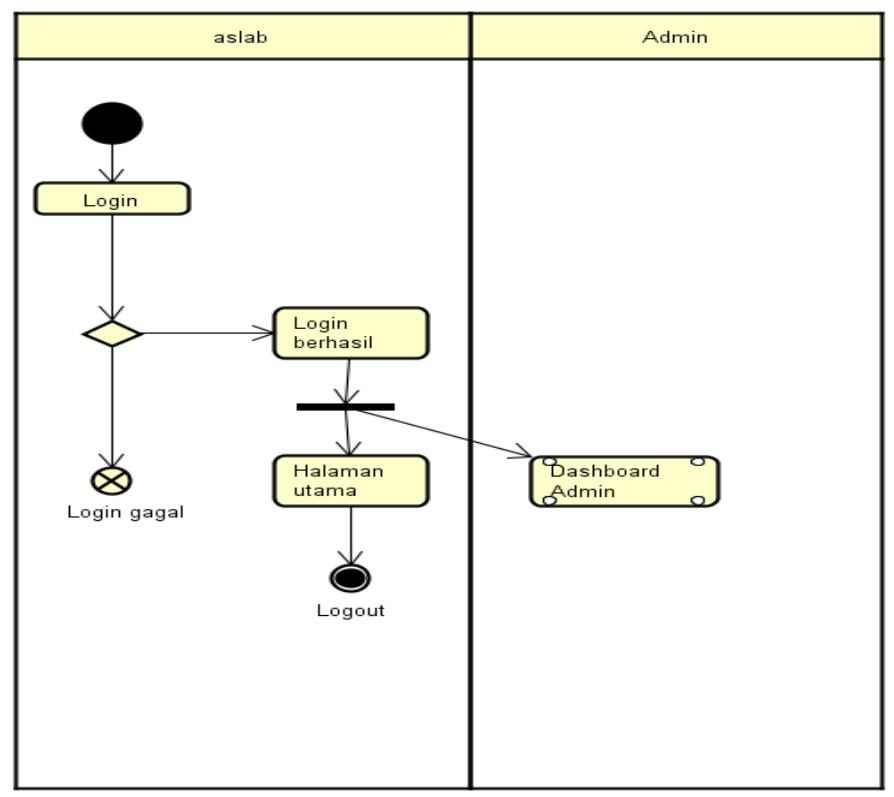

Figure 4

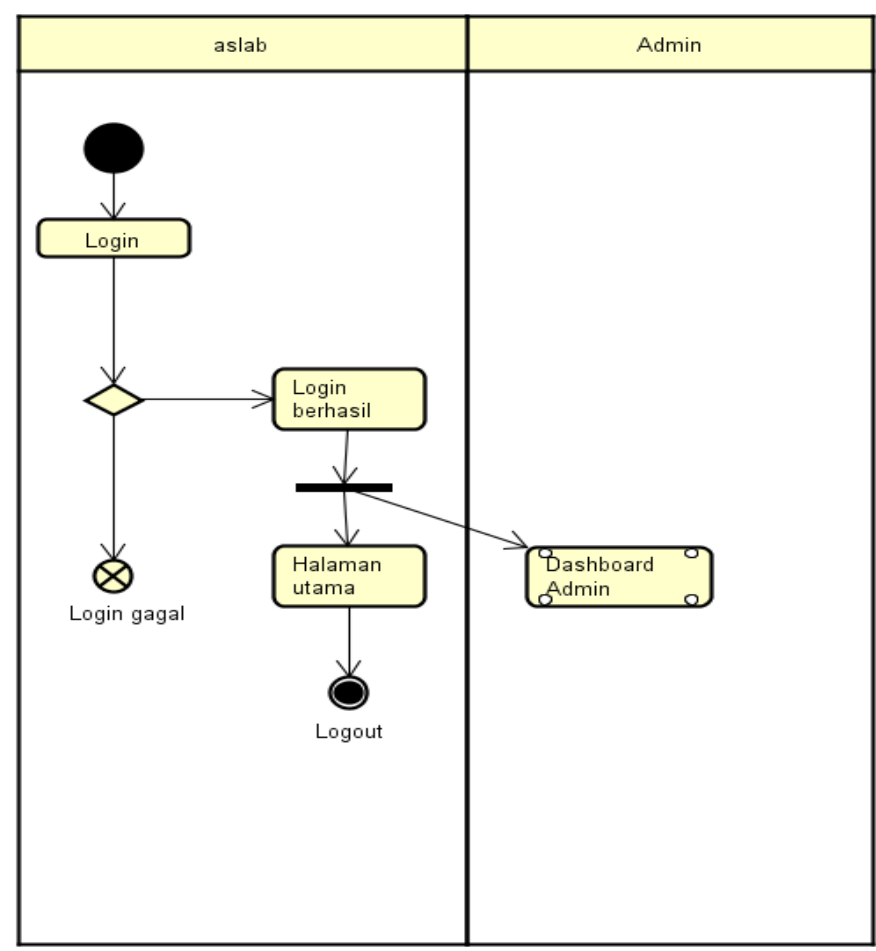

Figure 5

Figure 5 ASLAB opens the android application and $\operatorname{logs}$ into the application. Login fails if aslab is not registered in the database. Login is successful and the system is automatically present on the admin dashboard and logout aslab indicates that the work schedule has been completed. 


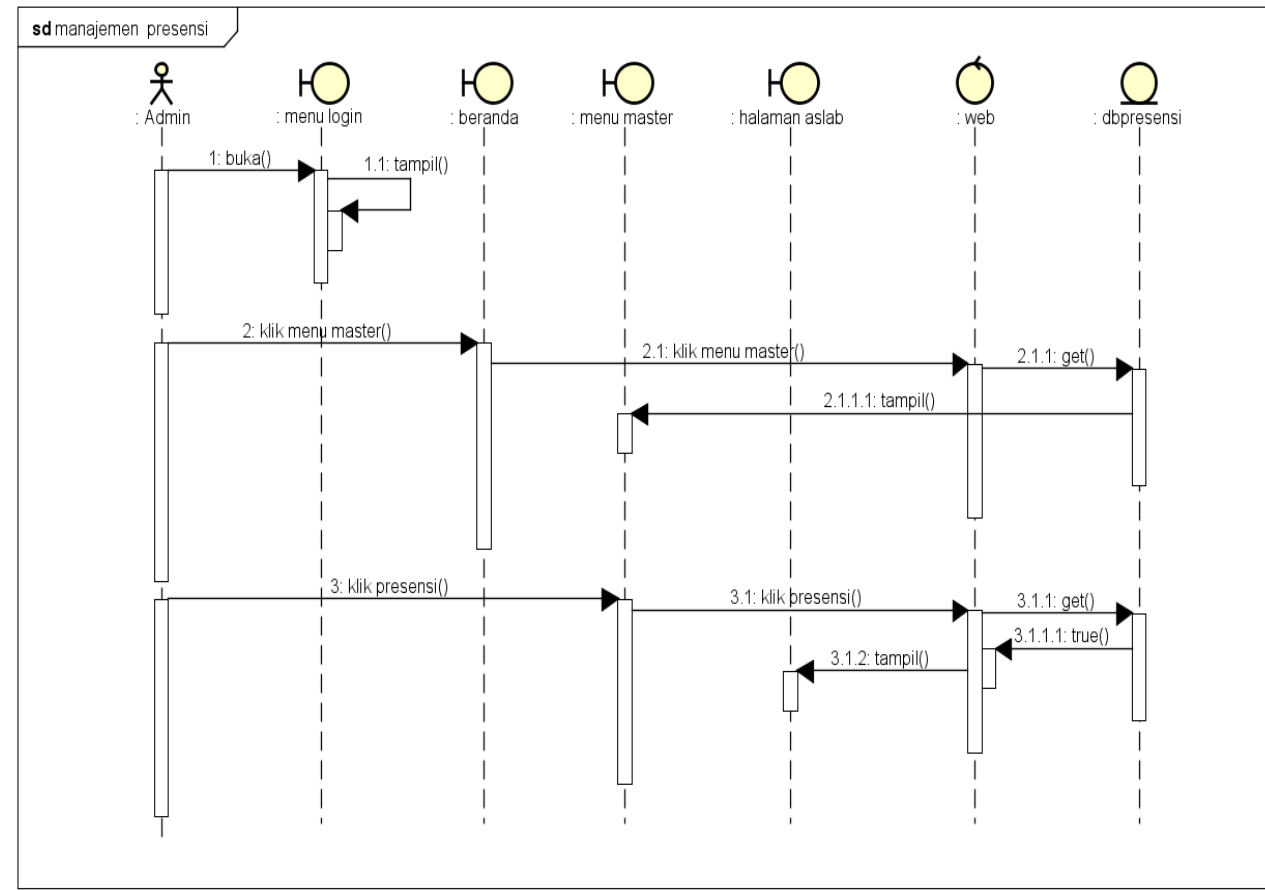

Figure 6 Sequence Diagram of presence Management

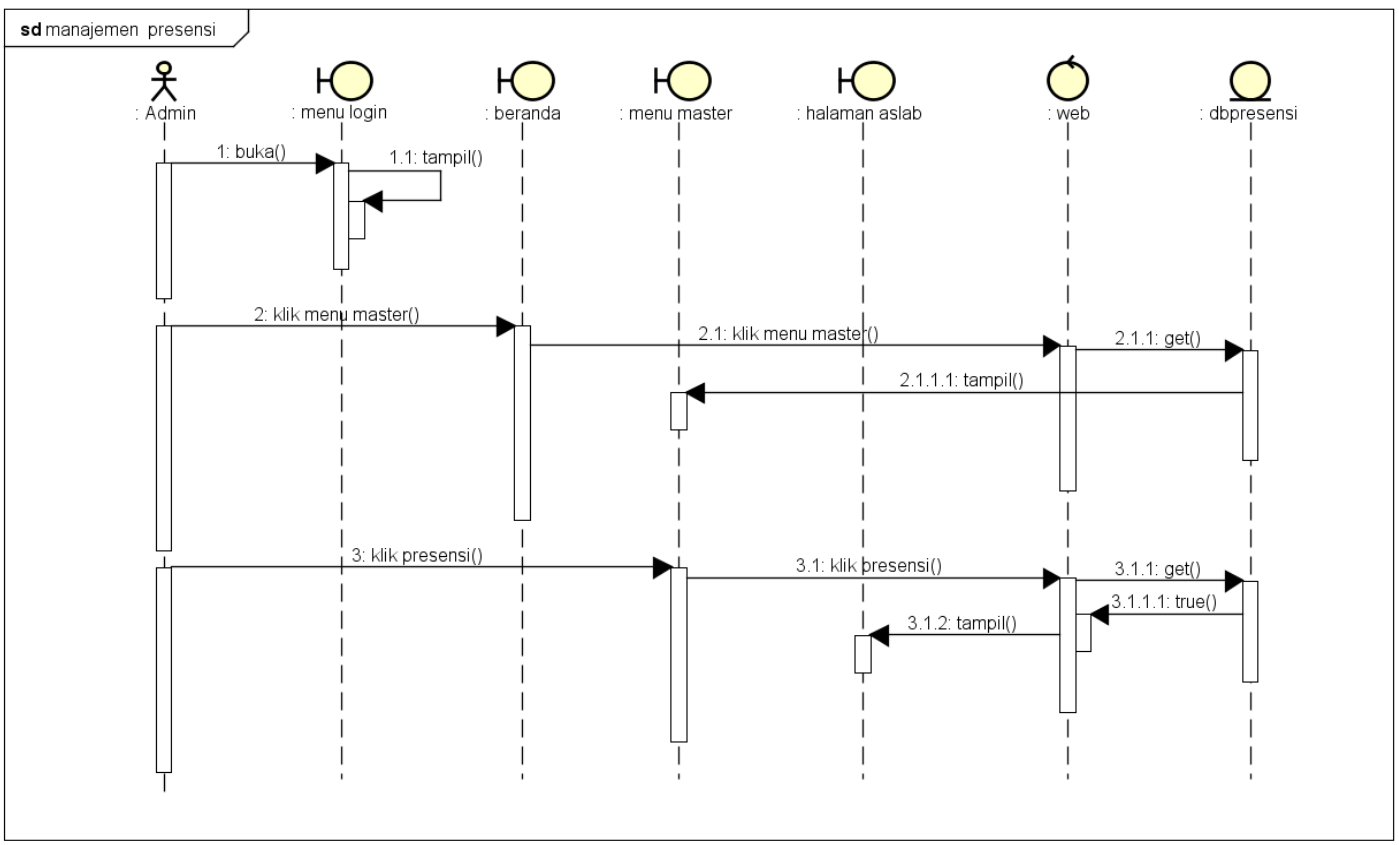

Figure 7 Sequence Diagram of Registration 


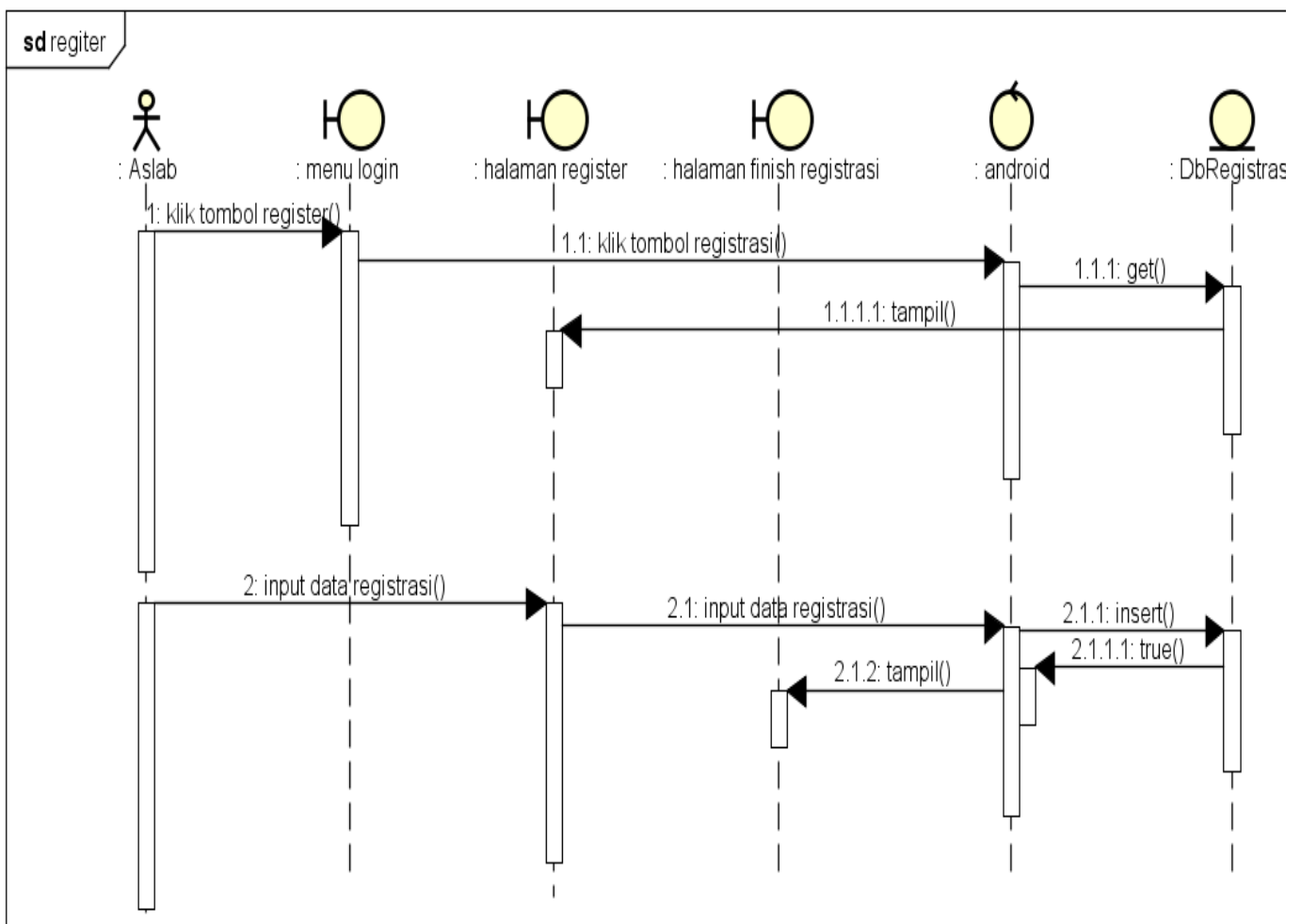

Figure 8 Sequence Diagram of Verification

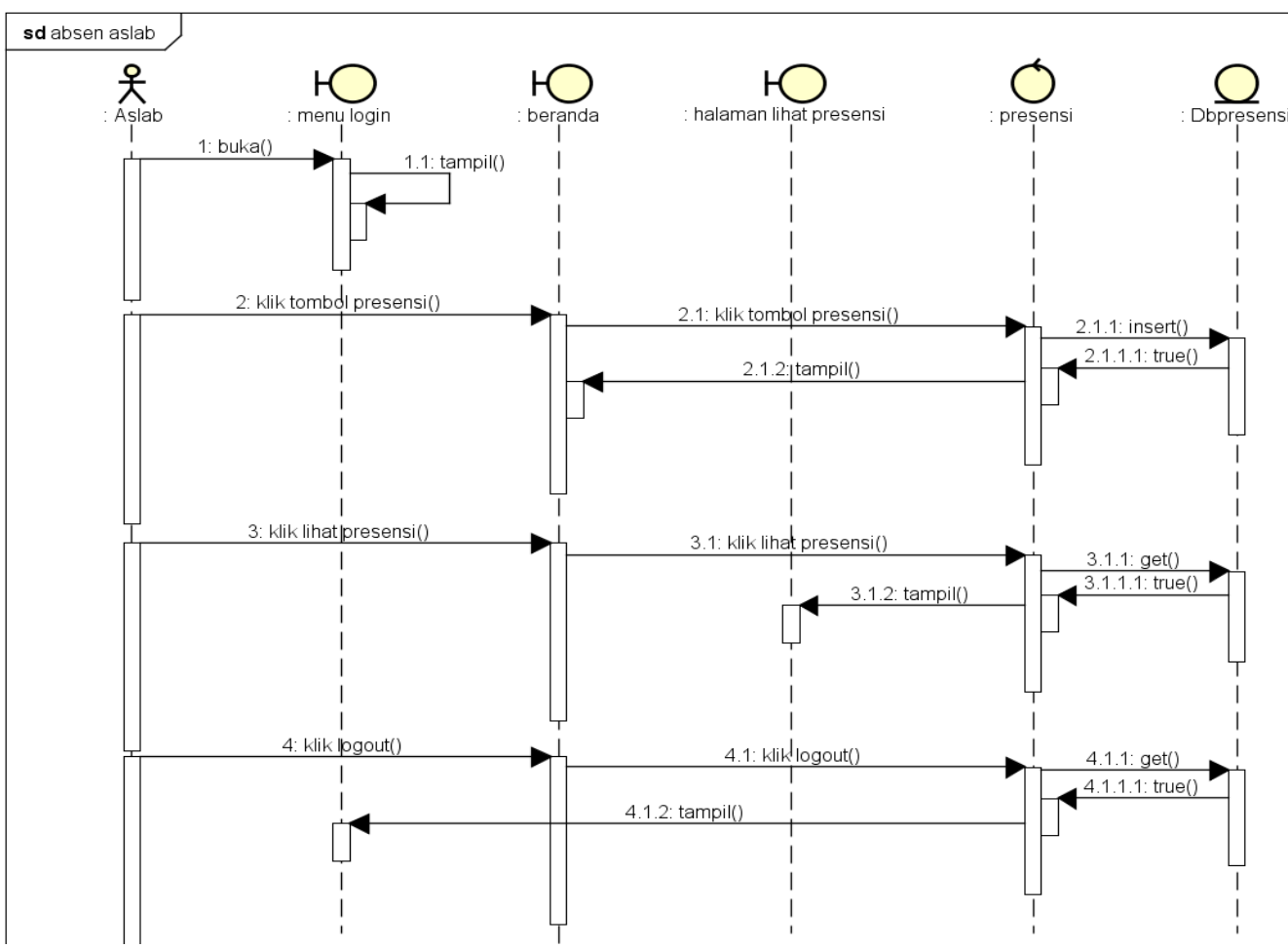

Figure 9 Sequence Diagram ofAttendance 
d. Class Diagram

Figure 10 is used to display the system structure of the classes in the presence system application in the PT.XYZ laboratory.

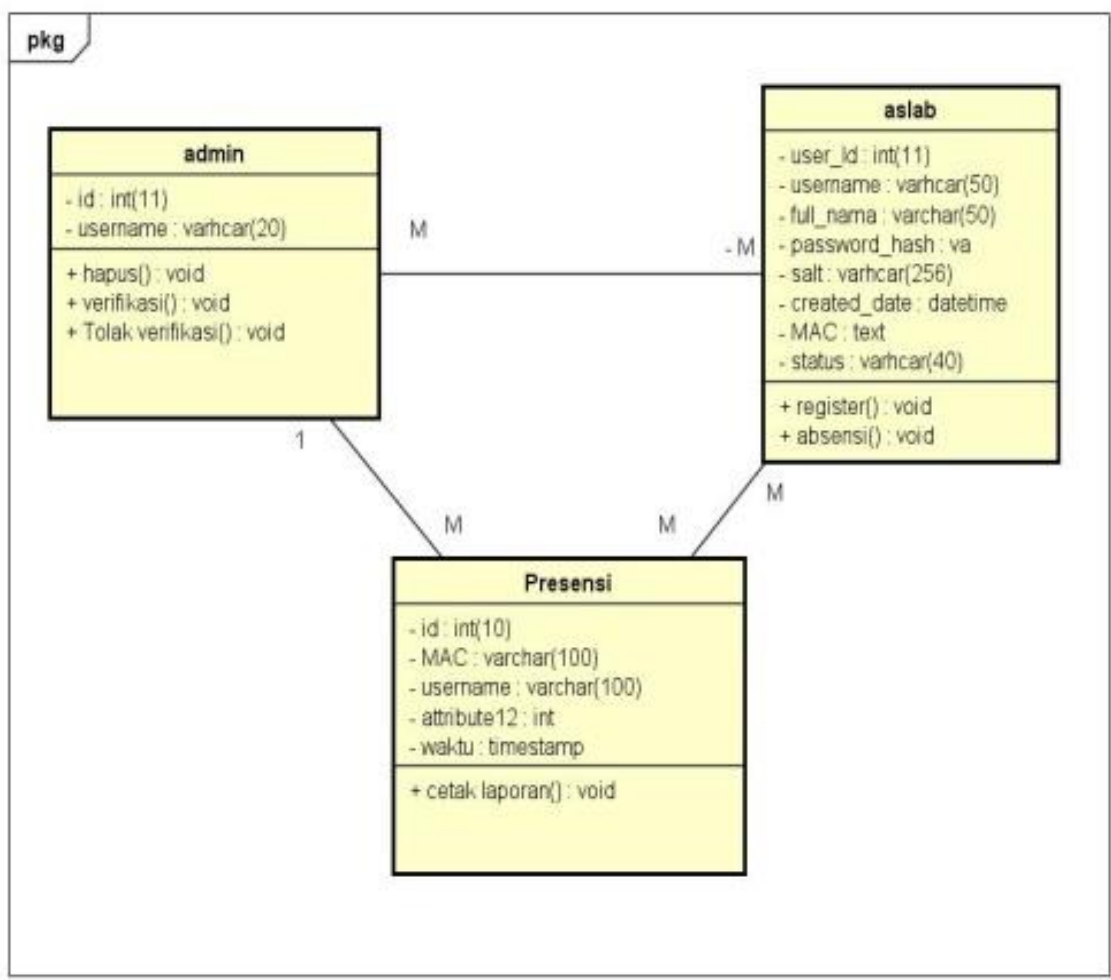

Figure 10 Class Diagram

\subsection{Implementation}

The implementation stage is the stage of application that has been designed is built and then tested according to what has been designed. The following will explain the implementation of the presence system application using Android-based wireless fidelity. Some example for design iterface of the application that are made are as follows:

a. Design Interface

1) Design Interface of Login Admin

Figure 11 shows the admin login screen that functions to log into the web server. The admin must enter the username and password to be able to login to the web server, then click the login button to enter the web server. if successful, the system will display the main web server page, if it fails the system will display the admin login page again. 


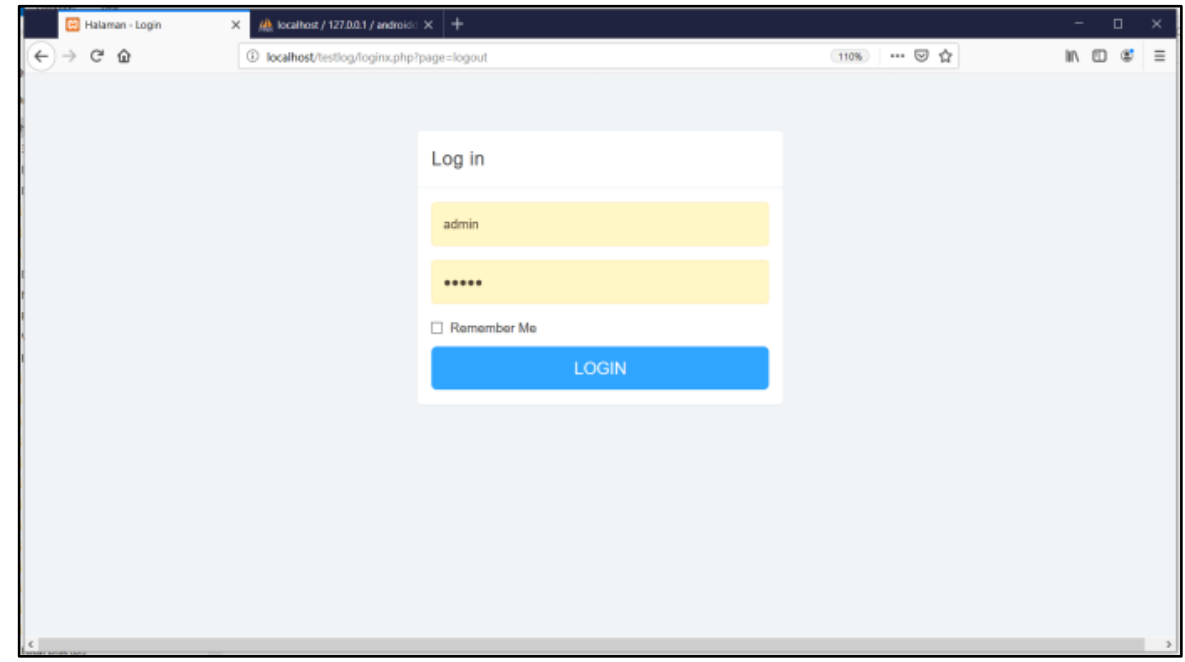

Figure 11 Login Admin

2) Design Interface of Main Admin Page

Figure 12 describes the screen display of the main web server page.

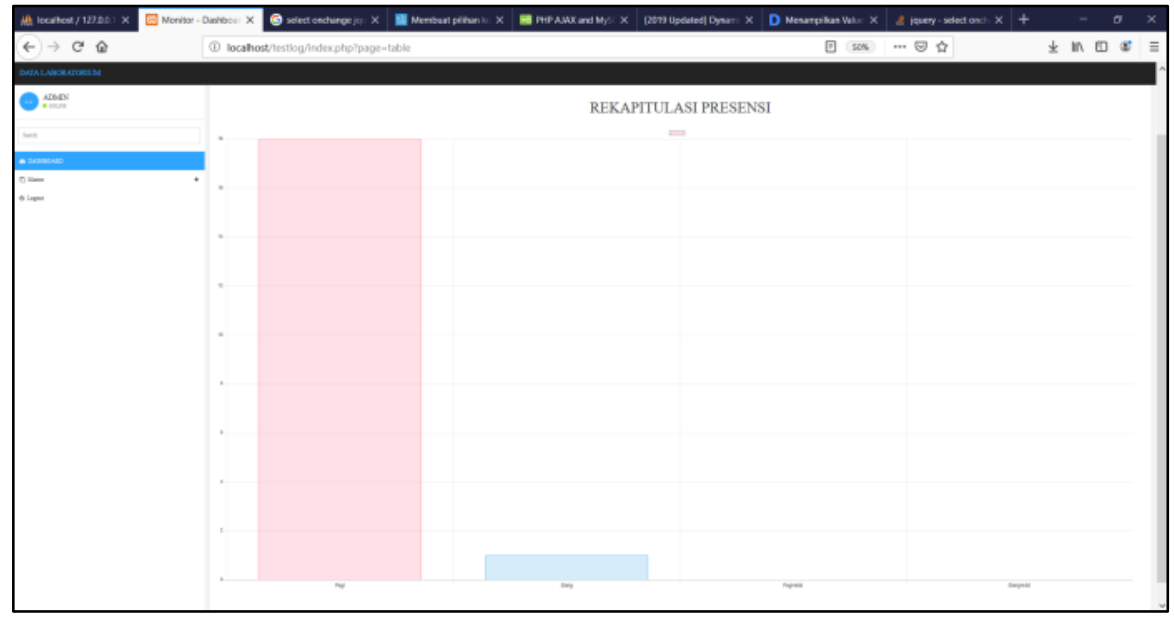

Figure 12 Admin Page

3) Design Interfance of Verification

Figure 13 shows the verification screen that serves to verify the aslab data that has registered. Only admins can access this page. 


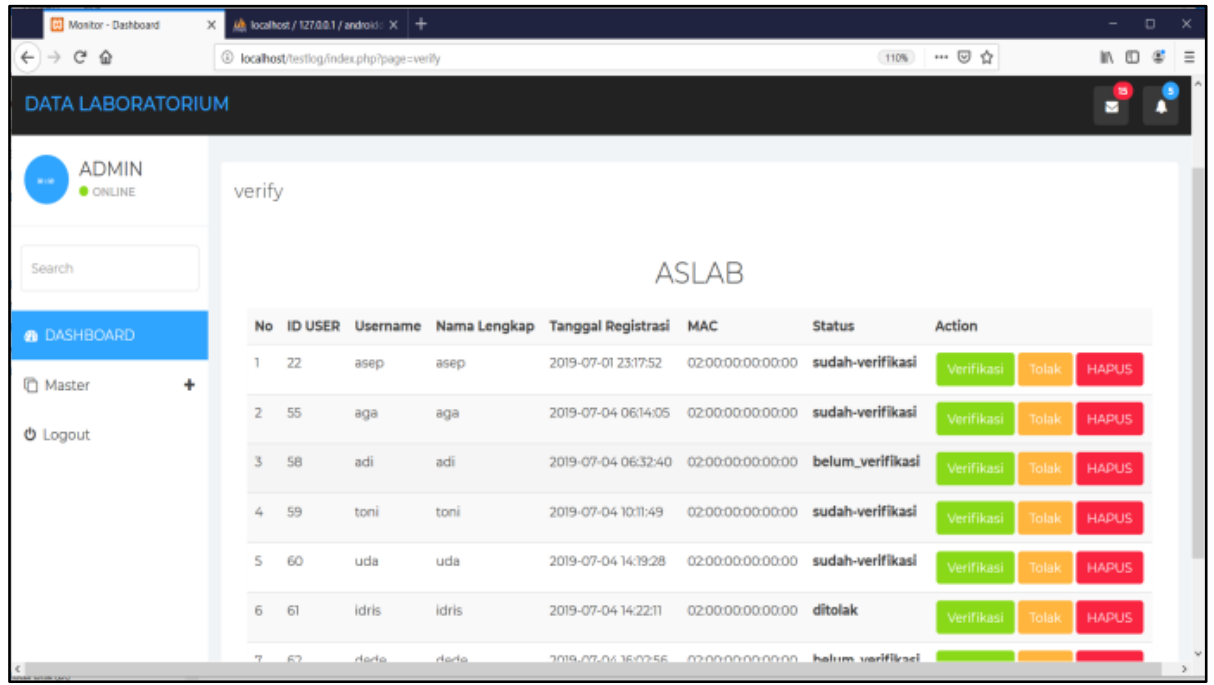

Figure 13 Verification Page

4) Design Interface of Attendance Page

Figure 14 shows the presentation page screen on a web server. This page can only be accessed by admin.

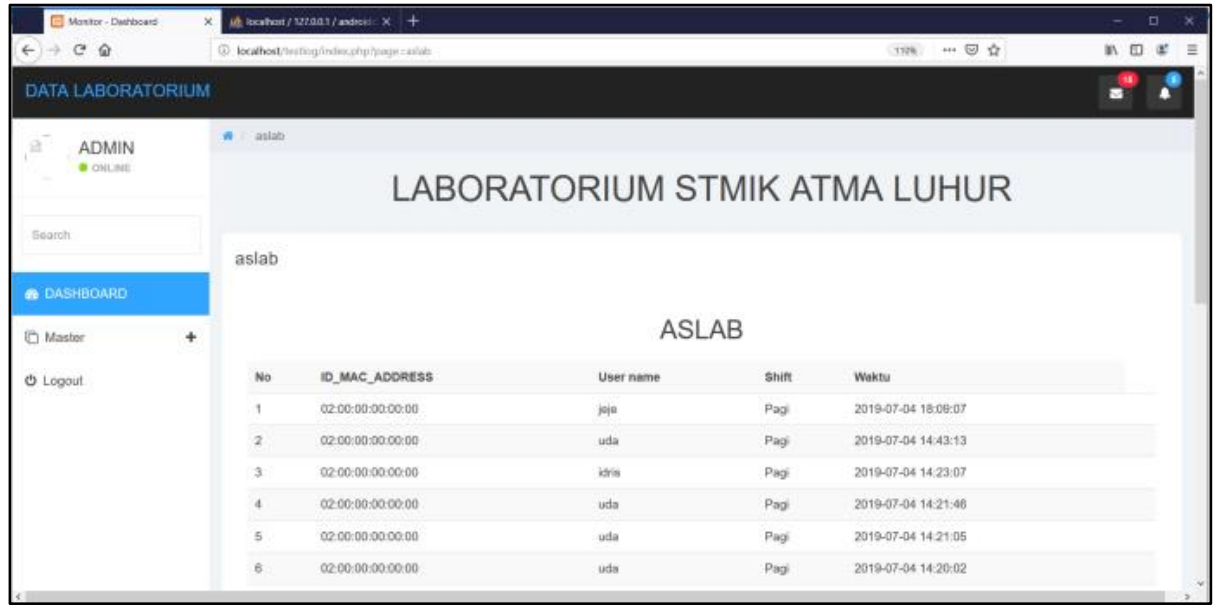

Figure 14 Attendance Page

5) Design Interface of ASLAB Login

Figure 15 shows the aslab login screen on the android application. This page can enter the main presence page by clicking sign in, but first, ASLAB must fill in the username and password. In addition, this page can take you to the registration page by clicking the register button. 


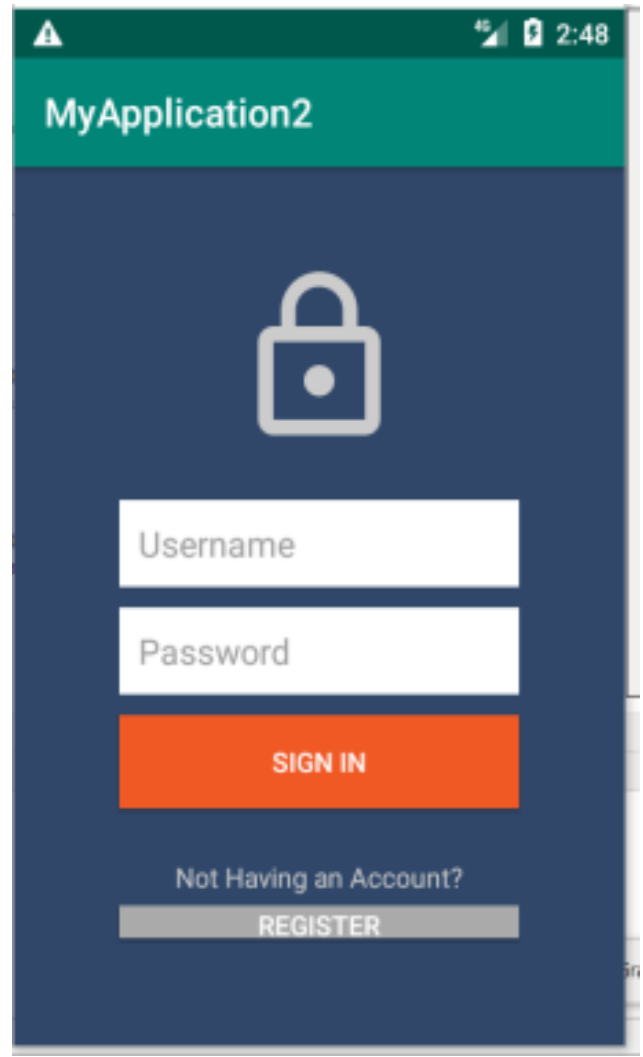

Figure 15 Aslab Login Page

6) Design Interface of Registration

Figure 16 shows the registration screen on the android application. On this page will be able to display the MAC address.

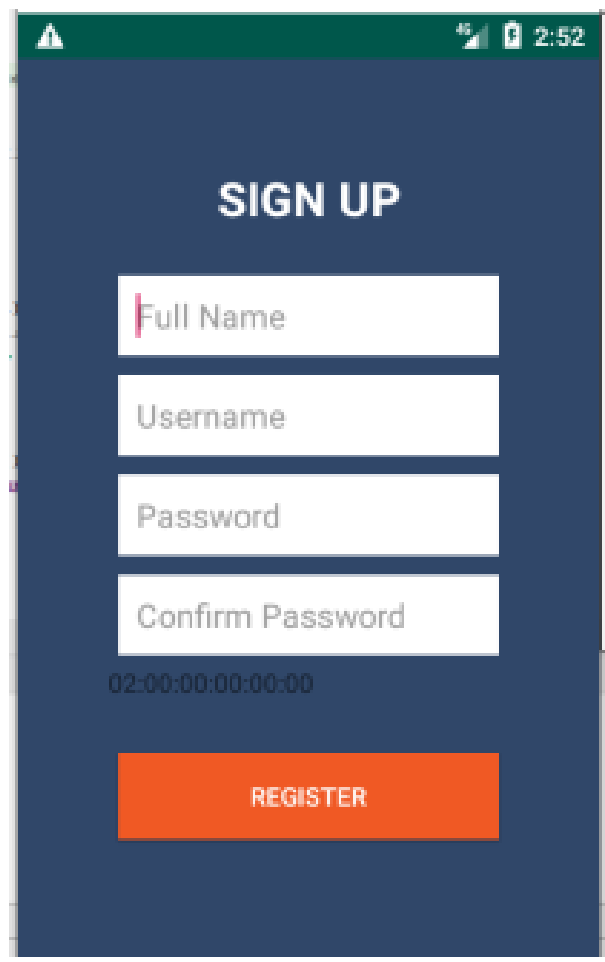

Figure 16 Registration Page 
7) Design Interface of Attendance

Figure 17 shows the main presence page on the android application. On this page you can also go to the view presence page. if not, The aslab can also logout from the application

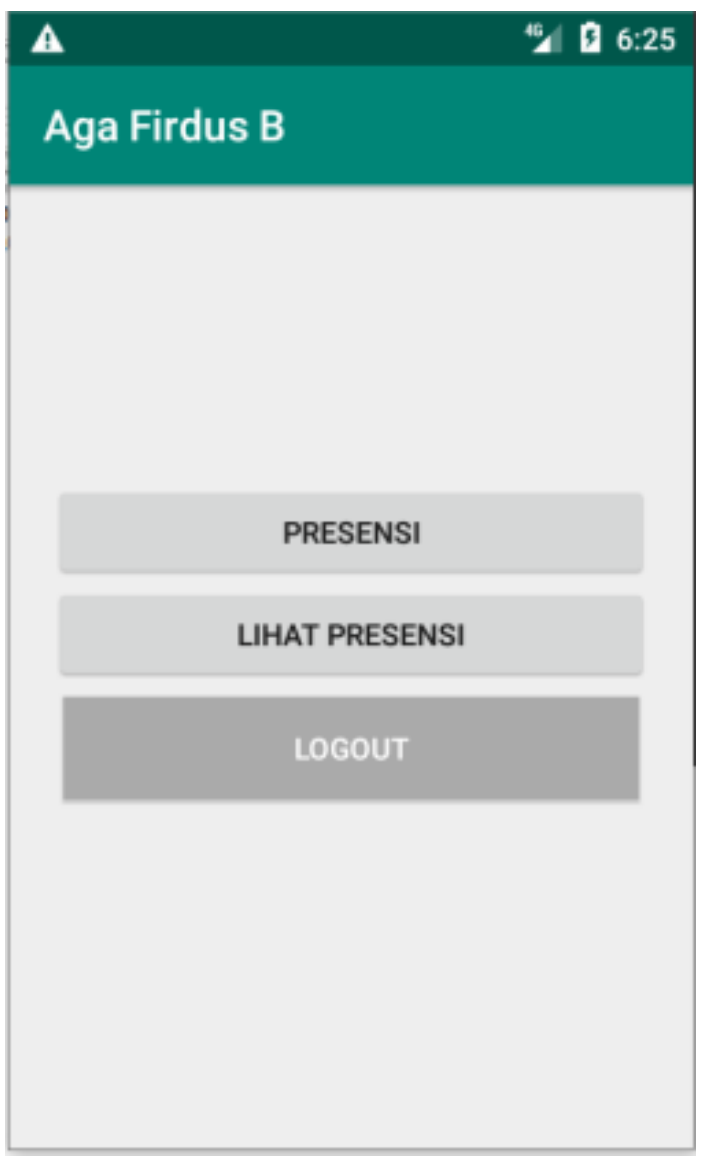

Figure 17 Attendance Page

b. BlackBox Testing

At this stage of testing the method used is the black box method. This black box method is used to determine whether the application is functioning properly and running as expected.

Table 1 Black Box Testing on web server of admin

\begin{tabular}{|c|l|l|l|c|}
\hline NO & Activity & Expectation Result & Result & Conclusion \\
\hline 1 & $\begin{array}{l}\text { In Login Page, admin } \\
\text { input username and } \\
\text { password that has been } \\
\text { saved in database }\end{array}$ & $\begin{array}{l}\text { Admin can login and } \\
\text { then show the main } \\
\text { page }\end{array}$ & Success & Valid \\
\hline 2 & $\begin{array}{l}\text { Admin can edit menus } \\
\text { and verification }\end{array}$ & $\begin{array}{l}\text { System can show the } \\
\text { menu of verification } \\
\text { page delete and } \\
\text { table of verification } \\
\text { menu }\end{array}$ & Sucess & Valid \\
\hline 3 & $\begin{array}{l}\text { Admin can chose edit } \\
\text { menus and attendance } \\
\text { menu }\end{array}$ & $\begin{array}{l}\text { The system will sow } \\
\text { attendance menu }\end{array}$ & Success & Valid \\
\hline
\end{tabular}


Table 2 Black Box Testing of user in Android Application

\begin{tabular}{|c|l|l|c|c|}
\hline NO & Activity & Expectation Result & Result & Conclusion \\
\hline 1 & Login & $\begin{array}{l}\text { Login success and show the } \\
\text { main page }\end{array}$ & Success & Valid \\
\hline 2 & Register & $\begin{array}{l}\text { The system will show } \\
\text { registration page and then fill } \\
\text { the registration form and the } \\
\text { system will show the finish } \\
\text { page of registration page and } \\
\text { show the mac address }\end{array}$ & Sucess & Valid \\
\hline 3 & $\begin{array}{l}\text { Attendance } \\
\text { main page }\end{array}$ & $\begin{array}{l}\text { The system can show the } \\
\text { attendance and then show } \\
\text { attendance and logout }\end{array}$ & Success & Valid \\
\hline 4 & $\begin{array}{l}\text { Attendance sub } \\
\text { page }\end{array}$ & $\begin{array}{l}\text { The system will show time of } \\
\text { presence and notification that } \\
\text { the presence has been done } \\
\text { and logout }\end{array}$ & Success & Valid \\
\hline 6 & Logout & The system can lougout & Success & Valid \\
\hline
\end{tabular}

\section{CONCLUSION}

Based on the experiments that has been tested, it can be concluded that by applying the WPA2 Enterprise authentication system it can also be used for the attendance system when connecting to a wifi network as incoming attendance data and when disconnected from the wifi network as outgoing attendance data. The daily attendance recap will be taken from the amount of data and then sorted based on the earliest data for incoming attendance data and the latest for outgoing attendance data.

Based on the results of the research conducted, it can be concluded that the application of the computer laboratory assistant attendance system in PT.XYZ using Android-based wireless fidelity has been successfully designed. Attendance of ASLAB in PT.XYZ work well and has no problem. And can decrease several problems like cheating on attendance to increase the preformance of aslab of PT. XYZ. Attendance using wireless fidelity can be option for other to use attendance using device around us.

\section{REFERENCES}

[1] Afgan, A, P., Yuli, A, P., dan Nia, A., 2015, Pengembangan Web E-Commerce Bojana Sari Menggunakan Metode Prototype, Jurnal Program Studi Sistem Informasi, Universitas Telkom, Bandung.

[2] Fajar Agung Wicaksono, Burhanudin Dirgantoro.Ir.MT, Surya Michrani Nasution ST.,MT, 2015, Perancangan Dan Prototipe Aplikasi Presensi Perkuliahan Dengan Menggunakan Android Pada Wireless Sensor Network Design And Prototype Of Presence Lectures Application With Android Smartphone On Wireless Sensor Network, Jurnal Prodi S1 Sistem Komputer, Fakultas Teknik, Universitas Telkom.

[3] Kadek, W., 2015, Analisa Konsep ObjectOriented Pada Bahasa Pemprograman PHP, Jurnal AMIK Bina Sarana Informatika, Jakarta Selatan. 
[4] Rosa, A.S, Salahudin, M, 2015, Rekayasa Perangkat Lunak Terstruktur dan Beroriantasi Objek, Informatika, Bandung.

[5] Rizky Dhanta, 2009, Pengantar Ilmu Komputer, Surabaya, INDAH.

[6] Khojimah, N, P, 2014, Aplikasi Jaket Kulit Berbasis Android Dengan Gis di Kota Bandar Lampung, Ilmu Komputer Fakultas Matematika Teknik dan Ilmu Komputer, Universitas Komputer Indonesia, Bandung.

[7] Marzuq, N, H, 2013 Sistem Informasi Single User Penerimaan Pesrta Didik Baru Berbasis Php di Sekolah Menengah Pertaa Islamiyah Widodaren Ngawi, Fakultas Teknik Informatika, Univ. Samawa, Sumbawa. Vol. 2. 1.

[8] Riyanto, 2014, Membuat Aplikasi Mini Market Integrasi Barcode Reader Dengan PHP dan MYSQL, Gava Media, Yogyakarta.

[9] M. Sidi, M., Reori, F, F., dan Hendra, R., 2016, Pengujian Aplikasi Menggunakan Black Box Testing Boundary Value Analysis, Jurnal Jurusan Teknik Informatika, Fakultas Teknik, Universitas Widyatama, Bandung.

[10] Muhammad Huzaimi Maulana, Anak Agung Rak P.W.A, Cindaya Dewi Andini, Faridatun Nadziroh., 2018, Sistem Peminjaman Ruangan Online (SPRO) dengan Metode UML (Unfield Modeling Language), Jurnal Teknologi dan Terapan Bisnis [JTTB], No.1, Vol,1, 2615-8817.

[11] Abdul Kadira, Kamaruddin Tone, 2015, Analisa Kerja Access Point Jaringan Wireles Pada Universitas Al Asyariah Mandar Fakultas Ilmu Komputer Universitas Al Asyariah Mandar

[12] http://e-journal.uajy.ac.id/8864/4/3TF06659.pdf

[13] https://fakhrikmt.blogspot.com/2018/06/pengertian-mac-address-fungsi-dan-cara.html

[14] Rahmat Sulaiman, R. Burham Isnanto, 2016, Pembuatan Sistem Untuk Peningkatan Kualitas Pada Lembaga Pendidikan Komputer XYZ, Jurnal TI Atma Luhur Vol. 3 No. 1

[15] Rahmat Sulaiman, Bambang Adiwinoto, 2018, Perancangan Ontologi Untuk Informasi Pariwisata Berbasis WEB SEMANTIK Guna Mendukung Pangkalpinang Dalam Pengembangan Smart City, Konferensi Nasional Sistem Informasi 2018 Pages 11751181 